\title{
Glibenclamide Unresponsiveness in a Brazilian Child with Permanent Neonatal Diabetes Mellitus and DEND Syndrome Due to a C166Y Mutation in KCNJ11 (Kir6.2) Gene
}

clinical case report

\author{
Thais Della ManNa \\ Claudilene Battistim \\ VANESSA RADONSKY \\ Roberta D. SAVOLDELLI \\ Durval Damiani \\ FERNANDO KOK \\ EWAN R. PEARSON \\ SIAN ELLARD \\ ANDREW T. HATTERSLEY \\ ANDRÉ F. REIS
}

Instituto da Criança do Hospital das Clínicas da Faculdade de Medicina da Universidade de São Paulo (TDM, CB, VR, RDS, DD,

FK), Fleury Medicina e Saúde

(FK); São Paulo, SP, Brasil;

Biomedical Research Institute,

Ninewells Hospital \& Medical

School (ERP), Dundee, United

Kingdom; Diabetes Research

department and the Centre for

Molecular Genetics at the

Peninsula Medical School and Royal Devon and Exeter Hospital (SE, ATH), Exeter, United Kingdom; Universidade Federal de São

Paulo, Laboratório de Endocrinologia Molecular (AFR), São Paulo, SP, Brasil.

Received in 10/9/2008

Accepted in 4/11/2008
ABSTRACT

Heterozygous activating mutations of KCNJ11 (Kir6.2) are the most common cause of permanent neonatal diabetes mellitus (PNDM) and several cases have been successfully treated with oral sulfonylureas. We report on the attempted transfer of insulin therapy to glibenclamide in a 4-year old child with PNDM and DEND syndrome, bearing a $\mathrm{C} 166 \mathrm{Y}$ mutation in KCNJ11. An inpatient transition from subcutaneous NPH insulin $(0.2$ units $/ \mathrm{kg} / \mathrm{d})$ to oral glibenclamide $(1 \mathrm{mg} /$ $\mathrm{kg} / \mathrm{d}$ and $1.5 \mathrm{mg} / \mathrm{kg} / \mathrm{d}$ ) was performed. Glucose and C-peptide responses stimulated by oral glucose tolerance test (OGTT), hemoglobin A1c levels, the 8-point self-measured blood glucose (SMBG) profile and the frequency of hypoglycemia episodes were analyzed, before and during treatment with glibenclamide. Neither diabetes control nor neurological improvements were observed. We concluded that $\mathrm{C} 166 \mathrm{Y}$ mutation was associated with a form of PNDM insensitive to glibenclamide. (Arq Bras Endocrinol Metab 2008; 52/8:1350-1355)

Keywords: Neonatal diabetes mellitus; KATP channels; KCNJ11; C166Y mutation; Glibenclamide; Treatment failure

\section{RESUMO}

Falha de resposta à Glibenclamida em Criança Brasileira com Diabetes Melito Neonatal Permanente e Síndrome DEND Devido a Mutação C166Y no Gene KCNJ11 (Kir6.2).

As mutações ativadoras, heterozigóticas do gene KCNJ11 (Kir6.2) são a causa mais freqüente de diabetes melito neonatal permanente (DMNP) e a terapêutica oral com sulfoniluréias tem sido bem sucedida em muitos destes casos. Relatamos o processo de substituição da insulinoterapia convencional para o tratamento oral com glibenclamida em uma paciente de 4 anos, portadora de DMNP e síndrome DEND devido a uma mutação C166Y no gene KCNJ11. A insulina NPH $(0,2 \mathrm{U} / \mathrm{kg} /$ dia) foi substituída pela glibenclamida $(1 \mathrm{mg} / \mathrm{kg} / \mathrm{dia}$ e $1,5 \mathrm{mg} / \mathrm{kg} / \mathrm{dia}$ ) durante internação hospitalar. As respostas de glicose e peptídeo-C no teste de tolerância oral à glicose (OGTT), os níveis de hemoglobina glicada, o perfil de glicemias capilares de 8 pontos e a freqüência de hipoglicemias foram comparados antes e durante o tratamento com glibenclamida. Não houve melhora no controle glicêmico, nem no quadro neurológico. Concluímos que a mutação $\mathrm{C} 166 \mathrm{Y}$ associa-se a uma forma de DMNP insensível à glibenclamida. (Arq Bras Endocrinol Metab 2008; 52/8:1350-1355)

Descritores: Diabetes melito neonatal; Canais KATP; KCNJ11; Mutação C166Y; Glibenclamida; Falha de tratamento

\section{INTRODUCTION}

eonatal diabetes mellitus (NDM) is a rare condition with an estimated incidence of 1:300.000 to 1:500.000 live births (1-4), defined as persis- 
tent hyperglycemia occurring within the first 6 months of life, lasting more than 2 weeks and requiring insulin therapy (5), and accordingly to the subsequent clinical course, it will be classified as permanent or transient (1).

Transient neonatal diabetes mellitus (TNDM) comprises approximately $50 \%$ of the cases and usually resolves in the first 18 months of life although requiring insulin therapy until resolution $(2,4,5)$; approximately one fourth of such cases will relapse from 7 to 20 years later (5).

Heterozygous activating mutations of KCNJll and $\mathrm{ABCC} 8$ are responsible for approximately $50 \%$ of permanent NDM (PNDM) (6-9). Defects in several other genes (IPF1, GCK, HNF1B, INS, FOXP3, EIF2AK3) have also been implicated in $\operatorname{PNDM}(4,9)$, however the activating mutations of KCNJll, which reduce the ability for ATP to close the ATP-sensitive potassium channel $\left(\mathrm{K}^{+}{ }_{\text {ATP }}\right)$, are the most common (6).

Glucose-stimulated insulin secretion is regulated by the closing of $\mathrm{K}_{\mathrm{ATP}}^{+}$channel which is an octameric complex of four pore-forming, inwardly rectifying potassium-channel subunits (Kir6.2) encoded by KCNJ11 gene and four regulatory sulfonylurea-receptor subunits (SURI) encoded by ABCC8 gene $(10,11)$.

Sulfonylureas have affinity to SURI and stimulate insulin secretion by an ATP-independent mechanism and can successfully replace insulin therapy to achieve a better metabolic control in several PNDM cases due to KCNJ11 mutations $(6,12)$. So the identification of a KCNJ11 mutation has implications for clinical management since many patients have been treated successfully with oral sulphonylureas rather than insulin (12-17).

Here we describe a case of a Brazilian child with PNDM and DEND syndrome (Developmental Delay, Epilepsy, Neonatal Diabetes) (18) due to a Cl66Y mutation in KCNJll gene and the results of the attempted transfer from insulin therapy to oral glibenclamide.

\section{SUBJECTS AND METHODS}

A Brazilian female child was born at 38 wk of gestation to a gravida 1 para 1 mother, whose pregnancy was uncomplicated, with a birth weight of $3000 \mathrm{~g}$, length of $48 \mathrm{~cm}$ and Apgar score: 8 and 9 . Her healthy parents were unrelated and the family history was remarkable for maternal grandparents with adult-onset diabetes and an aunt with diabetes and epilepsy. The postnatal course was uncomplicated and she was discharged home in the third day of life.
She was doing well until 3 months old when she manifested an exaggerated crying with irritability, and one month later she exhibited repeated head and limbs spasms followed by drowsiness. After physical and neurological examination, failure to thrive, muscle weakness, hypotonia and development delay were evident. A subsequent electroencephalogram showed slow background activity with multifocal spikes and slow wave complexes and then she was initiated on valproic acid $(40 \mathrm{mg} / \mathrm{kg} / \mathrm{d})$.

At the age of 5 months she developed fever, polyuria, irritability and laboratory work-up revealed glucosuria and a blood glucose level of $900 \mathrm{mg} / \mathrm{dL}$; however, ketoacidosis was not documented. She received intravenous normal saline and was started on subcutaneous insulin therapy with NPH human insulin and fast-acting insulin analogue (lispro) to correct hyperglycemia. Six days later she was discharged home in use of NPH $1.5 \mathrm{IU}$ in the morning and $1 \mathrm{IU}$ at bedtime, clobazam $(10 \mathrm{mg} / \mathrm{d})$ and valproic acid $(56 \mathrm{mg} / \mathrm{kg} / \mathrm{d})$.

The child was referred to our outpatient clinic at 13 months of age when she was not able to sit, speak syllables, or follow movements with eyes; her body weight was $8.000 \mathrm{~g}$ (-1.89 SDS), height was $71.5 \mathrm{~cm}$ (-1.88 SDS) and head circumference was $42.5 \mathrm{~cm}$ (-2.58 SDS). Anti-insulin and islet cell antibodies were negative.

At the age of 4 she presented failure to thrive (Weight $=-3.3$ SDS; Height= -4.2 SDS), microcephaly, severe development delay, muscle weakness, epilepsy, diabetes mellitus (Figure 1) and was classified as full DEND syndrome (18). A novel Cl66Y mutation in KCNJll was found by sequencing of the patient's KCNJll gene using genomic DNA extracted from peripheral lymphocytes by standard methods (19).

Parents were informed of the possible glibenclamide-related side effects and written informed consent was obtained before study initiation and after approval by local ethics committee. An inpatient transition from subcutaneous human NPH insulin therapy (0.2 units/ $\mathrm{kg} / \mathrm{d})$ to oral glibenclamide $(1 \mathrm{mg} / \mathrm{kg} / \mathrm{d})$ was performed during a 4 -week period followed by a washout phase with subcutaneous NPH insulin and a subsequent 4 -week trial with a higher oral glibenclamide dose $(1.5 \mathrm{mg} / \mathrm{kg} / \mathrm{d})(12)$. The primary outcome was insulin independence after a 4 -week period on glibenclamide, with a maximum dose of $1.5 \mathrm{mg} / \mathrm{kg} / \mathrm{d}$. Correction bolus doses with fast-acting insulin analogue (lispro) were done every time blood glucose levels were $\geq 200 \mathrm{mg} / \mathrm{dL}$. 


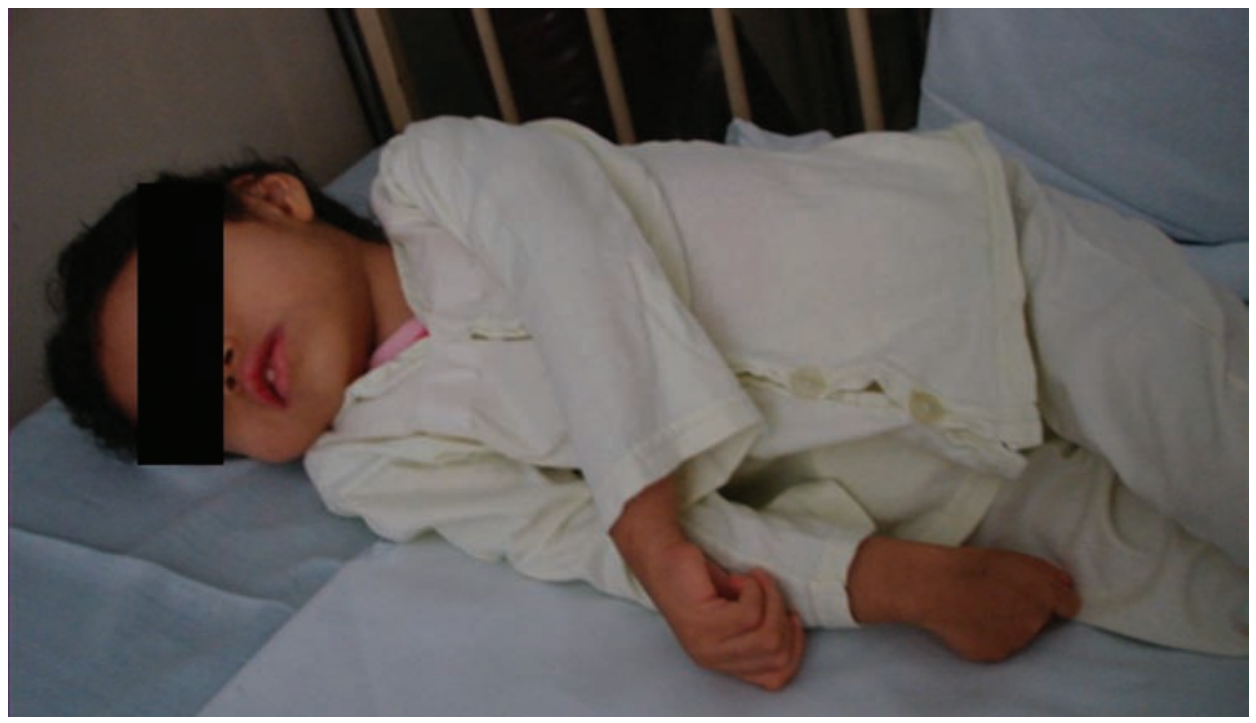

Figure 1. Four-year old child with DEND syndrome due to a Cl66Y mutation in KCNJ1 1 (Kir6.2). Note severe development delay, limb spasticity and failure to thrive.

Glucose and C-peptide stimulated by 2 -hour oral glucose tolerance test (OGTT, $1.75 \mathrm{~g} / \mathrm{kg}$, standard method) were compared immediately before and after transition to oral glibenclamide $(1 \mathrm{mg} / \mathrm{kg} / \mathrm{d})$. Hemoglobin Alc levels (HPLC, Bio-Rad Laboratories, Hercules, CA, USA), the 8-point self-measured blood glucose $(\mathrm{SMBG})$ profile and the frequency of hypoglycemia episodes registered in Camit-Pro software for Accu-chek ${ }^{\circledR}$ glucometers were compared before and during treatment with glibenclamide $(1 \mathrm{mg} / \mathrm{kg} / \mathrm{d})$, during subcutaneous NPH insulin washout phase and during reintroduction of a higher dose of glibenclamide $(1.5 \mathrm{mg} / \mathrm{kg} / \mathrm{d})$. Data were expressed as mean $\pm \mathrm{SD}$; differences between groups were assessed by Student's t-test and ANOVA, $\mathrm{p}<0.05$ was considered significant.

Stimulated mean blood glucose level was significantly higher during glibenclamide $(1 \mathrm{mg} / \mathrm{kg} / \mathrm{d})$ treatment than with NPH insulin therapy $(250 \pm 80$ vs 160 $\pm 54 \mathrm{mg} / \mathrm{dL} ; \mathrm{p}<0.01)$ and no difference between stimulated mean plasma C-peptide $(0.46 \pm 0.20$ vs $0.26 \pm$ $0.22 \mathrm{ng} / \mathrm{mL}$ ) response was observed during oral glibenclamide and NPH insulin therapy, respectively ( $\mathrm{Fi}-$ gure 2). Another OGTT with oral glibenclamide (1.5 $\mathrm{mg} / \mathrm{kg} / \mathrm{d}$ ) was not performed.

Neither hemoglobin Alc levels, nor the 8-point SMBG profile and frequency of hypoglycemic events were different during oral glibenclamide ( 1 and 1.5 $\mathrm{mg} / \mathrm{kg} / \mathrm{d}$ ) and NPH insulin therapy, respectively $(\mathrm{Fi}-$ gures 3, 4 and 5). No side effects related to glibenclamide or neurological improvement were observed; however correction boluses of lispro insulin were required once to four times a day during glibenclamide treatment.

Since insulin independence was not achieved, the child returned on NPH and lispro insulin therapy and now is maintaining an adequate metabolic control.

\section{DISCUSSION}

The effectiveness of oral sulfonylurea in improving glycemic control of diabetic patients due to KCNJll mutations after transfer from insulin therapy has been confirmed by many reports, with doses ranging from 0.05 to $1.5 \mathrm{mg} / \mathrm{kg} / \mathrm{d}(12-17)$; however data concerning the use of sulfonylurea in the treatment of PNDM with DEND syndrome have shown variable results. Several mutations related to severe DEND syndrome (Q52R, G53R, V59G, I296L, G334D) are insensitive to glibenclamide $(4,12,19,20)$; nevertheless in some forms of intermediate DEND syndrome (Il67L, G53D, H46L, V59M), characterized by less severe developmental delay and without epilepsy, glibenclamide therapy has improved metabolic control, neuromuscular symptoms (17,2l-24) and even cognition (V59M) (25). Evidence that sulfonylurea could change CNS blood flow and function was provided by the use of 


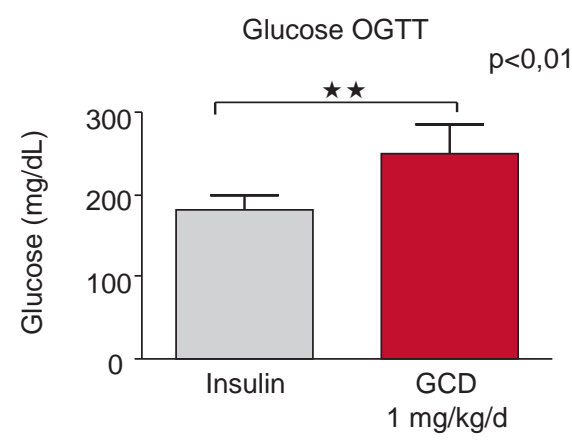

C-Peptide OGTT

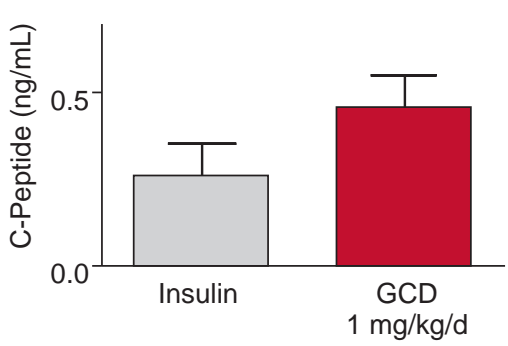

Figure 2. Comparison of OGT-stimulated glucose and plasma C-peptide responses during NPH insulin therapy $(0.2$ units/kg/d) and glibenclamide (GCD) (1 mg/kg/d). (Student † test).

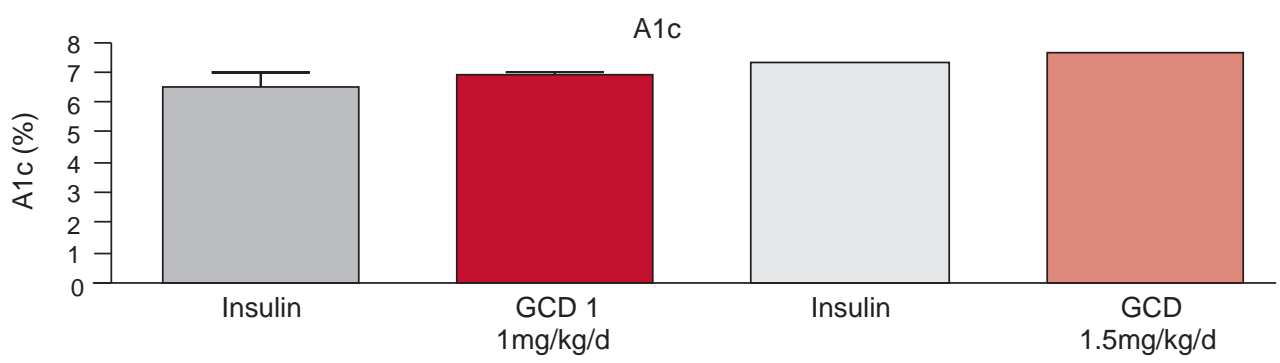

Figure 3. Comparison of $\mathrm{HbAlc}$ during NPH insulin therapy and oral glibenclamide (GCD) $1 \mathrm{mg} / \mathrm{kg} / \mathrm{d}$ and $1.5 \mathrm{mg} / \mathrm{kg} / \mathrm{d}$. (ANOVA).

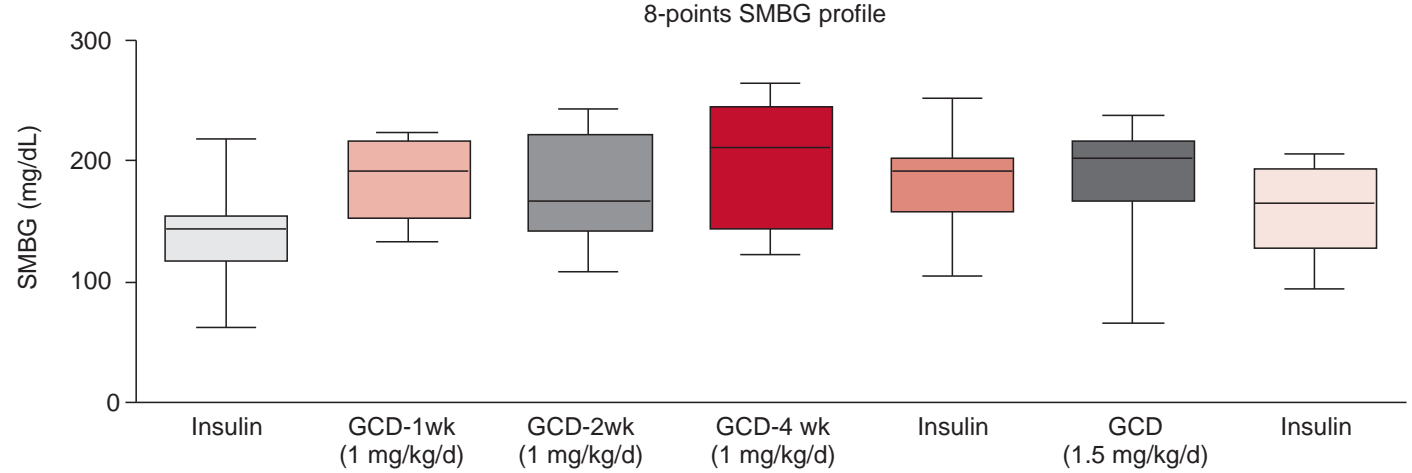

Figure 4. Comparison of OGT-stimulated glucose and plasma C-peptide responses during NPH insulin therapy (0.2 units/kg/d) and glibenclamide (GCD) (1 mg/kg/d). (Student t test).

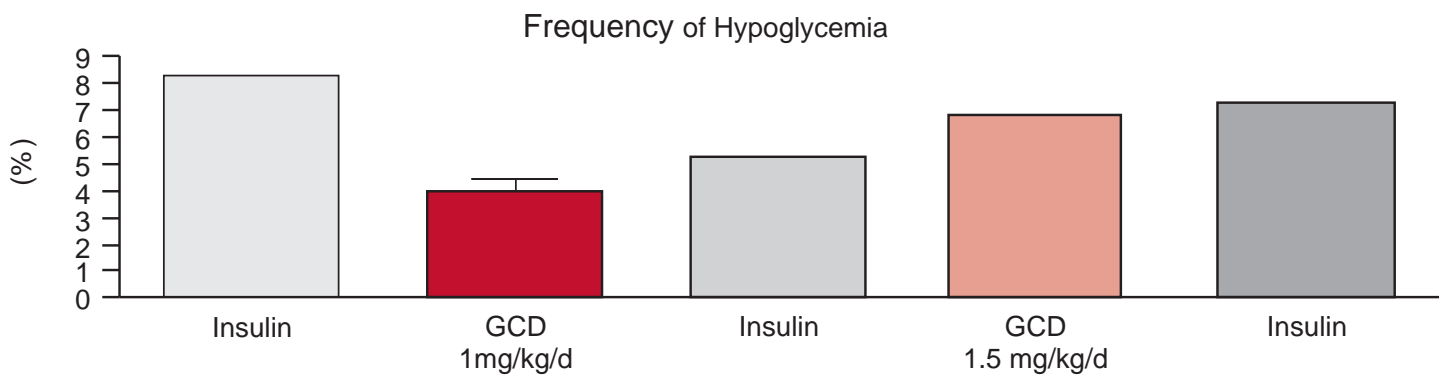

Figure 5. Comparison of hypoglycemia frequency during NPH insulin therapy and oral glibenclamide (GCD) $1 \mathrm{mg} / \mathrm{kg} / \mathrm{d}$ and 1.5 $\mathrm{mg} / \mathrm{kg} / \mathrm{d}$. (ANOVA). 
single-photon emission CT (SPECT) imaging, before and after glibenclamide therapy (24).

The first patient described with a mutation at $\mathrm{co}^{-}$ don 166 with substitution of cysteine by phenylalanine (Cl66F) presented with neonatal diabetes, full DEND syndrome and dysmorphic features including prominent metopic suture, bilateral ptosis and down turned mouth, but she died from aspiration pneumonia at the age of 6 months after partial and transitory control of epilepsy with tolbutamide $(0.75 \mathrm{mg} / \mathrm{kg} / \mathrm{d})$ combined with ACTH therapy $(26,27)$. Afterwards, Flanagan $e t$ al. (19) demonstrated the C166Y mutation (substitution of cysteine by tyrosine) in our patient, followed by another case (Cl66Y) described by Suzuki et al. (28) of neonatal diabetes with DEND syndrome, dysmorphic facial features and arthrogryposis who has been treated exclusively with insulin.

Kir6.2 is expressed in several tissues including pancreatic $\beta$-cell, brain, heart and skeletal muscle; Kir6.2 mutations associated with DEND syndrome are believed to be less sensitive to ATP than those that cause isolated diabetes, and functional studies supported a relationship between the site of the mutation and the ability of the channel to close in the presence of $\operatorname{ATP}(19,29)$.

The underlying molecular mechanism on the reduction of ATP sensitivity varies accordingly to the site of Kir6.2 mutations, which can be located in the ATPbinding site or in regions involved in channel gating. Some mutations may influence both ATP binding and gating, as well as the mechanism of signal transduction to channel closure $(29,30)$. In this regard, Trapp and cols. (31) demonstrated experimentally that mutations at residue 166 that replace cysteine - an hydrophobic amino acid, by larger and less hydrophobic amino acids increased the channel open probability, suggesting that the altered intrinsic gating kinetics should be the primary channel defect in these cases, what would explain the unresponsiveness to sulfonylurea therapy. Phenylalanine has a similar hydrophobicity to cysteine but is much larger, causing an increase in the channel open probability (31), and tyrosine is both larger and less hydrophobic than cysteine.

On the other hand, less severe phenotypes have been associated with mutations that cause defects in either ATP binding or gating (30). Thus, clinical phenotype will be determined mainly by the degree of channel activation rather than the gene involved (4).
In conclusion, we have demonstrated that a child with permanent neonatal diabetes mellitus and DEND syndrome due to a $\mathrm{Cl} 66 \mathrm{Y}$ mutation in $\mathrm{KCNJl}$ gene was insensitive to glibenclamide. This lack of clinical response was observed both for diabetes control and neurological features.

Acknowledgements: The molecular genetic work in Exeter was supported by the Wellcome Trust. No other potential conflict of interest relevant to this article was reported.

\section{REFERENCES}

1. von Muhlendahl KE, Herkenhoff H. Long-term course of neonatal diabetes. N Engl J Med. 1995;333:704-8.

2. Shield JPH, Gardner RJ, Wadsworth EJK, Whiteford ML, James RS, Robinson DO, et al. Aetiopathology and genetic basis of neonatal diabetes. Arch Dis Child. 1997;76:F39-F42.

3. Polak M, Cavè H. Neonatal diabetes mellitus: a disease linked to multiple mechanisms. Orphanet J Rare Dis. 2007;2:12.

4. Aguilar-Bryan L, Bryan J. Neonatal diabetes mellitus. Endocrine Rev. 2008;29:265-91.

5. Sperling MA. Neonatal diabetes mellitus: from understudy to center stage. Curr Opin Pediatr. 2005;17:512-8.

6. Gloyn AL, Pearson ER, Antcliff JF, Proks P, Bruining GJ, Slingerland AS, et al. Activating mutations in the gene encoding the ATP-sensitive potassium-channel subunit Kir6.2 and permanent neonatal diabetes. N Engl J Med. 2004;350:1838-49.

7. Babenko AP, Polak M, Cave H, Busiah K, Czernichow P, Scharfmann $R$, et al. Activating mutations in the ABBC8 gene in neonatal diabetes mellitus. N Engl J Med. 2006;355:456-66.

8. Ellard S, Flanagan SE, Girard CA, Patch AM, Harries LW, Parrish $A$, et al. Permanent neonatal diabetes caused by dominant, recessive, or compound heterozygous SUR1 mutations with opposite functional effects. Am J Hum Genet. 2007;81 (2):375-82.

9. Edghill EL, Flanagan SE, Patch AM, Boustred C, Parrish A, Shields $B$, et al. Insulin mutation screening in 1,044 patients with diabetes: mutations in the INS gene are a common cause of neonatal diabetes but a rare cause of diabetes diagnosed in childhood or adulthood. Diabetes. 2008;57(4):1034-42.

10. Aguilar-Bryan L, Clement IV, Gonzalez G, Kunjilmar K, Babenko A, Bryan J. Toward understanding the assembly and structure of $K_{A T P}$ channels. Physiol Rev. 1998;78:227-45.

11. Reis AF, Velho G. Patologia molecular do receptor de sulfoniluréia (SUR1). Arq Bras Endocrinol Metab. 2000;44:382-9.

12. Pearson ER, Flechtner I, Njolstad PR, Malecki MT, Flanagan SE, Larkin B, et al. Switching from insulin to oral sulfonylureas in patients with diabetes due to Kir6.2 mutations. N Engl J Med. 2006;355:467-77.

13. Sagen JV, Raeder H, Hathout E, Shehadeh N, Gudmundsson K, Baevre $\mathrm{H}$, et al. Permanent neonatal diabetes due to mutations in KCNJ11 encoding Kir6.2: patient characteristics and initial response to sulfonylurea therapy. Diabetes. 2004;53:2713-8.

14. Zung A, Glaser B, Nimri R, Zadik Zvi. Glibenclamide treatment in permanent neonatal diabetes activating mutation in Kir6.2. J Clin Endocrinol Metab. 2004;89:5504-7.

15. Klupa T, Edghill EL, Nazim J, Sieradzki J, Ellard S, Hattersley AT, Malecki MT. The identification of a $\mathrm{R} 201 \mathrm{H}$ mutation in 
KCNJ11, which encodes Kir6.2, and successful transfer to sustained-release sulphonylurea therapy in a subject with neonatal diabetes: evidence for heterogeneity of beta cell function among carriers of the R201H mutation. Diabetologia. 2005;48: 1029-31.

16. Codner E, Flanagan S, Ellard S, Garcia H, Hattersley AT. Highdose glibenclamide can replace insulin therapy despite transitory diarrhea in early-onset diabetes caused by a novel R201L Kir6.2 mutation. Diabetes Care. 2005;28(30):758-9.

17. Slingerland AS, Nuboer R, Hadders-Algra M, Hattersley AT, Bruining GJ. Improved motor development and good longterm glycaemic control with sulfonylurea treatment in a patient with the syndrome of intermediate developmental delay, early-onset generalized epilepsy and neonatal diabetes associated with the V59M mutation in the KCNJ11 gene. Diabetologia. 2006;49:2559-63.

18. Hattersley AT, Ashcroft FM. Activating mutations in Kir6.2 and neonatal diabetes: new clinical syndromes, new scientific insights, and new therapy. Diabetes. 2005;54:2503-13.

19. Flanagan SE, Edghill EL, Gloyn AL, Ellard S, Hattersley AT. Mutations in KCNJ11, which encodes Kir6.2, are a common cause of diabetes diagnosed in the first 6 months of life, with the phenotype determined by genotype. Diabetologia. $2006 ; 49$ (6): 1190-7.

20. Masia R, Koster JC, Tumini S, Chiarelli F, Colombo C, Nichols CG, Barbetti F. An ATP-binding mutation (G334D) in KCNJ11 is associated with a sulfonylurea-insensitive form of developmental delay, epilepsy, and neonatal diabetes. Diabetes. 2007; 56:328-36.

21. Shimomura $\mathrm{K}$, Horster $\mathrm{F}$, de Wet $\mathrm{H}$, Flanagan $\mathrm{SE}$, Ellard $\mathrm{S}$, Hattersley AT, et al. A novel mutation causing DEND syndrome. Neurology. 2007;69:1342-9.

22. Gurgel LC, Crispim F, Noffs MH, Belzunces E, Rahal MA, Moises RS. Sulfonylurea treatment in permanent neonatal diabetes due to G53D mutation in the KCNJ11 gene: improvement in glycemic control and neurological function. Diabetes Care. 2007;30:e108.

23. Koster JC, Cadario F, Peruzzi C, Colombo C, Nichols CG, Barbetti $F$. The G53D mutation in Kir6.2 (KCNJ11) is associated with neonatal diabetes and motor dysfunction in adulthood that is improved with sulfonylurea therapy. J Clin Endocrinol Metab. 2008;93:1054-61.
24. Mlynarski W, Tarasov Al, Gach A, Girard CA, Pietrzak I, Zubcevic $L$, et al. Sulfonylurea improves CNS function in a case of intermediate DEND syndrome caused by a mutation in KCNJ11. Nat Clin Pract Neurol. 2007;3:640-5.

25. Slingerland AS, Hurkx W, Noordam K, Flanagan SE, Jukema JW, Meiners LC, et al. Sulphonylurea therapy improves cognition in a patient with the V59M KCNJ11 mutation. Diabetic Medicine. 2008;25:277-81.

26. Gloyn AL, Diatloff-Zito C, Edghill EL, Bellanné-Chantelot $C$, Nivot S, Coutant R, et al. KCNJ11 activating mutations are associated with development delay, epilepsy and neonatal diabetes syndrome and other neurological features. Eur J Hum Gen. 2006;14:824-30.

27. Bahi-Buisson N, Eisermann M, Nivot S, Bellanné-Chantelot $C$, Dulac O, Bach N, et al. Infantile spasms as an epileptic feature of DEND syndrome associated with an activating mutation in the potassium adenosine triphosphate (ATP) channel, Kir6.2. J Child Neurol. 2007;22(9):1147-50.

28. Suzuki S, Makita Y, Mukai T, Matsuo K, ueda O, Fujieda K. Molecular basis of neonatal diabetes in Japanese patients. J Clin Endocrinol Metab. 2007;92(10):3979-85.

29. Proks P, Antcliff JF, Lippiat J, Gloyn AL, Hattersley AT, Ashcroft FM. Molecular basis of Kir6.2 mutations associated with neonatal diabetes or neonatal diabetes plus neurological features. Proc Nat Acad Sci USA. 2004;101:17539-44.

30. Shimomura K. The K(ATP) channel and neonatal diabetes. Endocr J. 2008 Jun 20. [Epub ahead of print].

31. Trapp S, Proks P, Tucker SJ, Ashcroft FM. Molecular analysis of ATP-sensitive $K$ channel gating and implications for channel inhibition by ATP. J Gen Physiol. 1998;112:333-49.

\section{Correspondence to:}

Thais Della Manna

Av. Pedroso de Moraes, 427

05419-000 São Paulo SP

E-mail: thais.manna@icr.usp.br 